\title{
Carbon Emission Reduction Potential through Sustainable Forest Management in Forest Concession of PT Salaki Summa Sejahtera, Province of West Sumatera
}

\author{
Iwan Hilwan ${ }^{1 *}$, Andry Indrawan ${ }^{1}$, Supriyanto ${ }^{1}$, Teddy Rusolono ${ }^{2}$ \\ ${ }^{1}$ Department of Silviculture, Faculty of Forestry, Bogor Agricultural University, \\ Academic Ring Road, Campus IPB Dramaga, PO Box 168, Bogor 16680, Indonesia \\ ${ }^{2}$ Department of Forest Management, Faculty of Forestry, Bogor Agricultural University, \\ Academic Ring Road, Campus IPB Dramaga, PO Box 168, Bogor 16680, Indonesia.
}

Received June 13, 2012/Accepted July 2, 2012

\begin{abstract}
A management unit (MU) of a forest concession holder implementing the sustainable forest management (SFM) principles, could be involved in reducing Emmission from Reforestation and Forest Degradation (REDD+) and carbon trading project. The fact the strategic in implementing the REDD+ and carbon trading in MU level is still lack of pilot project and methodology. Therefore, some scenarios must be developed and tested to find out the best potential of carbon credit in MU level. The objectives of the research were: to calculate carbon credit in some SFM scenarios, to analyze of carbon trading project feasibility, and to determine carbon stock recovery period of logged over area (LOA). The result revealed that carbon stock and carbon credit of LOA was affected by timber cutting intensity. The $6^{\text {th }}$ scenario with lowest annual allowable cutting (AAC) obtained greater carbon credit and profit coming from timber harvesting income and carbon trading. In other hand, this scenario has shortest duration of carbon stock recovery period (27 years) and shorter than its cutting cycle. In this case, the MU has to recalculate and to decrease its AAC to have highest benefits from carbon trading in the same cutting cycle period. It will provide double benefits from carbon trading, those are contribution in achieving the SFM purposes (production, ecology, social) and climate change mitigation.
\end{abstract}

Keywords: sustainable forest management, AAC, carbon stocks, recovery period, carbon trading

*Correspondence author, email: ihilwan@yahoo.co.id, telp. +62-812-8534575

\section{Introduction}

The mitigation of climate change in forestry sectors involves various elements such as management unit (MU) in Business Permit for the Utilization of Timber Forest Product Natural Forest, which will be mentioned as IUPHHK-HA afterward. According to the Minister of Forestry Regulation (Permenhut) No. P.30/Menhut-II/2009, the work area of IUPHHK-HA is also a designated site to implement the program of reducing emissions from deforestation and forest degradation (REDD). MU that undertakes REDD/REDD+ is required to practice sustainable forest management (SFM). SFM implementation by MU contributes to the climate change mitigation both through increasing carbon stock and reduction of carbon emission. Furthermore, implementation of SFM opens an opportunity for the MU to receive financial benefit from carbon trading via REDD+ scheme. Prospective of economic benefit of the forest carbon is thought to be excessive, taking into account the capacity of carbon sequestration and carbon sink of forests. Economic benefit will be given when MU succeeded to accumulate required amount of carbon credit from various forest management activities that increase the carbon sequestration. Permenhut No. P.36/Menhut-II/2009 underlines examples of production management practices in SFM that result in carbon credit such as extending cutting rotation, increasing the limit of cutting diameter, reducing the annual allowable cut, and enrichment planting and reforestation. Therefore, it is important to analyze the magnitude of carbon credit obtained by MU when it is involved in practices carbon credit generating SFM, and to calculate its economic benefit when MU is involved in carbon trading project. The analyzed management activities were set up in several formulation of cutting intensity and were then compared to baseline scenario as its reference. Related to SFM, it is important, as well, to understand the scenario that brought about the shortest phase duration of carbon stock recovery. The present research was intended to approximate the magnitude of carbon stock and carbon credit brought about from several wood utilization scenarios in the frame of SFM, approximate the duration of recovery period of logged over area (LOA), analyzing the feasibility of carbon trading project endeavor, and analyzing the interrelation of SFM practices, recovery period and carbon trading project.

\section{Methods}

Research site and time Primary and secondary data were compiled during November 2011 in the work area of PT Salaki Summa Sejahtera (PT SSS) in Siberut Island, Regency of Mentawai Archipelago-West Sumatera. Primary data were gathered from virgin forest (ABD) and LOA 2008, 2009, 
2010, and 2011 of Tiniti forest blocks. Certain supporting data was obtained from references and Tiniti base camp of PT SSS.

Wood utilization scenario Six SFM scenarios of wood utilization were modeled. They were formulated based on parameters of cutting rotation, diameter at breast height limit (dbh), without encroacher disturbances, and implementation of reduced impact logging (RIL). The reference of the just mentioned scenarios was baseline scenario, i.e. wood utilization in forests management without the implementation of SFM with the parameters of highest cutting intensity, encroacher disturbances, and performing conventional logging (CL) (Table 1).

Lengthened cutting rotation can increase carbon stock (Sasaki \& Cheng 2011). RIL reduced carbon emission, decreased the degradation of residual stand and decreased harvesting waste (Putz et al. 2008b) when compared to CL. This study used 30 years project duration in the effective production area of 33,205 ha of the PT SSS. Relevant primary and secondary data, as well as certain assumptions and price standard were used to estimate carbon potential and financial analysis.

Estimation of stand carbon stock Gain-loss method (GOFC-GOLD 2009) was used to estimate above the ground forest carbon stock. Harvesting activities, degradation of residual stand due to logging, stand cutting during forest opening, and forest encroachment are the loss factors of carbon stock. On the other hand, enrichment planting, rehabilitation planting, wood necromass, and growth volume are the gain factors of forest carbon stock. Gain-loss was calculated by equation [1]:

$\Delta \mathrm{C}=\Delta \mathrm{C}_{\text {gain }}-\Delta \mathrm{C}_{\text {los }}$

note:

$\Delta \mathrm{C}=$ annual carbon stock change $\left(\mathrm{tCO}_{2} \mathrm{e} \mathrm{year}^{-1}\right)$

$\Delta \mathrm{C}_{\text {gain }}=$ annual carbon stock gain $\left(\mathrm{tCO}_{2} \mathrm{e}_{\text {year }}{ }^{-1}\right)$

$\Delta \mathrm{C}_{\text {loss }}=$ annual carbon stock loss $\left(\mathrm{tCO}_{2} \mathrm{e}\right.$ year $\left.{ }^{-1}\right)$

Loss factors of carbon stock were used to calculate the stand volume of the LOA at the first year after cutting. Stand volume before cutting was using the resulting 2010 IHMB data of PT SSS. The stand volume of LOA was calculated by equation [2]:

$V t_{1}=\left(V t_{0} P-K-T-D\right) \times L$

note:

$V t_{l}=$ stand volume of LOA at $t_{l}\left(\mathrm{~m}^{3}\right)$

$V t_{0}=$ initial stand volume $\left(\mathrm{m}^{3} \mathrm{ha}^{-1}\right)$

$P=$ the volume of cut wood $\left(\mathrm{m}^{3} \mathrm{ha}^{-1}\right)$

$K=$ the volume of heavily degraded wood due to logging $\left(\mathrm{m}^{3} \mathrm{ha}^{-1}\right)$

$T=$ stand volume during forest opening $\left(\mathrm{m}^{3} \mathrm{ha}^{-1}\right)$

$D=$ lost stand volume due to encroaching $\left(\mathrm{m}^{3} \mathrm{ha}^{-1}\right)$

$L=$ annual allowable cut (ha year ${ }^{-1}$ )

The following equation [3] was used to calculate the change of annual stand volume during the project:

$V_{t}=(n-t) L\left(V_{t 0}+t R_{1}\right)+L\left(t V_{t 1} \sum_{i=l}^{t-1} t_{i}=R_{2}\right.$

note :

$V t=$ stand volume at the-t year of the project

$n$ = cutting rotation (year)

$t=$ the $\mathrm{t}^{\text {th }}$ year of the project $(\mathrm{t}=1,2, \ldots, 30)$

$L=$ annual cutting area(ha)

$V_{t 0}=$ stand volume in the beginning of the project (IHMB data)

$V_{t l}=$ stand volume of LOA at $t_{l}$

$R_{l}=$ regrowth or growth volume in virgin forest (before cutting) (ABD) $\left(\mathrm{m}^{3}\right.$ ha year $\left.{ }^{-1}\right)$

$R_{2}=$ regrowth or growth volume at LOA stand $\left(\mathrm{m}^{3} \mathrm{ha}^{-1}\right.$ year $\left.{ }^{-1}\right)$

Wood necromass Wood necromass signify the mass of expired wood biomass in the form of both standing and toppled trees. Measured wood necromass was those with the dimensions of $\geq 10 \mathrm{~cm} \mathrm{dbh}$ (standing), $\geq 10 \mathrm{~cm}$ in base diameter, and $\geq 0.5$ in length (toppled). Calculation of the decomposition rate of wood necromass was using the equation [4] (GOFC-GOLD 2009).

$X_{t}=X_{0} \mathrm{e}^{k t}$

note :

$X_{t}=$ weight of wood necromass at year $t^{\text {year }}$

$X_{\mathrm{o}}=$ initial weight of wood necromass

$k=$ coefficient of decomposition $(0.5)$

e $=$ base $\operatorname{logarithm}(2.7183)$

$t=$ time (year)

Table 1 Wood utilization scenario

\begin{tabular}{cccccccc}
\hline Scenario & $\begin{array}{c}\text { Cutting } \\
\text { rotation (year) }\end{array}$ & $\begin{array}{c}\text { Dbh limit } \\
(\mathrm{cm})\end{array}$ & $\begin{array}{c}\text { Logging } \\
\text { method }\end{array}$ & \% AAC & $\begin{array}{c}\text { Cutting } \\
\text { intensity } \\
\left(\mathrm{m}^{3} \mathrm{ha}^{-1}\right)\end{array}$ & $\begin{array}{c}\text { Area AAC } \\
\left(\text { ha year }^{-1}\right)\end{array}$ & $\begin{array}{c}\text { Volumetric AAC } \\
\left(\mathrm{m}^{3} \text { year }^{-1}\right)\end{array}$ \\
\hline Baseline & 30 & 40 & CL & 100 & 82,21 & 1,107 & $91,006.47$ \\
1 & 30 & 50 & RIL & 100 & 71,74 & 1,107 & $79,416.18$ \\
2 & 30 & 60 & RIL & 100 & 59,86 & 1,107 & $66,265.02$ \\
3 & 30 & 40 & RIL & 75 & 61,66 & 1,107 & $68,257.62$ \\
4 & 35 & 40 & RIL & 100 & 82,21 & 949 & $78,017.29$ \\
5 & 35 & 50 & RIL & 100 & 71,74 & 949 & $68,081.26$ \\
6 & 35 & 60 & RIL & 100 & 59,86 & 949 & $56,807.14$ \\
\hline
\end{tabular}


Forest encroachment Forest encroachment is a form of forest interference due to human activities through forest opening exploited for long term farming activities. Therefore, it is frequently trigger deforestation. Deforestationresulted from encroachment need to be immediately predicted and seriously to be taken into account due to its threat on the sustainability of forests. The encroached forest area is closely related to the growth rate of population, number of family member, number of farmer, farming area needed per family, and social responsibility program of PT SSS.

Stand degradation of LOA by logging Intensity of LOA stand degradation due to logging (felling and skidding) of trees $\geq 20 \mathrm{~cm}$ dbh referred to Indriyati (2010). The calculated data were the number of the heavily degraded trees only, since such a stand will expire and become the source of the new wood necromass. The intensity of pole degradation ( $\mathrm{dbh}$ 10-19.9 cm) was referring to Elias (2001) with an assumption that $70 \%$ of pole stratum is heavily degraded. Implementation of RIL in SFM scenario was assumed will decrease the residual stand degradation by $50 \%$ compared to that of baseline scenario with CL implementation (Pinard \& Putz 1996). Furthermore, reduction of harvesting intensity and the increase of cutting diameter limit decrease the number of tree degradation (Feldpausch et al. 2005). The number of tree felled in forest opening activities (commonly clear cutting) was calculated based on the area of opened forest for forest opening according to annual work working plan (RKT) of 2008, 2009, and 2010 multiplied by the stand density of IHMB 2010.

Cutting waste Cutting waste from wood harvesting referred to Partiani (2010). It was assumed that all cutting wastes were left in cutting block.

Enrichment planting growth Shorea selanica Bl. was chosen for enrichment planting and it was planted in both sides of the ex-skidding trail with the distance of $5 \mathrm{~m}$ between trees in a row. Estimation of carbon stock of $S$. selanica was based on data resulted from the growth evaluation of $S$. selanica in Haurbentes-Bogor (Istomo et al. 1999). Diameter data was obtained from the equation of $Y=0.6095 X^{1,13}\left(R^{2}=\right.$ 0.99 ) where $X=$ the age of plant and $Y=\mathrm{dbh}$, and the height was with the equation of $Y=0.4808 X^{1,22}\left(R^{2}=0.99\right)$. Specific gravity of $S$. selanica wood was 0.46 and it was assumed that the number of plant grown until the end of the project was $60 \%$.

The growth of rehabilitation plant Intolerant fast growing species such as gmelina (Gmelina arborea Roxb.), sungkai (Peronema canescens Jack), and sengon (Paraserianthes falcataria (L.) Nielsen) were planted for rehabilitation planting. Estimation of the carbon stock of rehabilitation plant until the end of the project was just represented by sengon since alometric equation of fast growing species were not reasonably different. Rehabilitation planting was carried out in both the right and left sides of the main road, branch road, and bare land previously used for log yard.

The percentage of opened forest area for the establishment of main road, branch road, and bare land was based on the realization of forest opening and annual work plan 2008, 2009, and 2010. Planting distances applied were in accordance with that applied by PT SSS. Sengon wood specific gravity is 0.33 and it was assumed that the percentage of plant grown at the end of the project was $60 \%$. The increase of sengon diameter until the end of the project (at plant age of 27 years) was predicted through the formulation of regression line based on data for the sengon growth up to 8 years old from Riyanto and Pamungkas (2010). Sengon biomass was estimated by the alometric equation of $Y=0,1126 D^{2,3445}$ (Siringoringo \& Siregar 2006 in Krisnawati et al. 2011). At the age of 10 years old sengon was cut and the cleared area was replanted with sengon.

Estimation of stand carbon content Estimation of the potential of stand carbon content was preceded by calculating the mass of stand biomass based on biomass conversion and expansion factors (BCEF) of 1 , in which the stand volume $\left(\mathrm{m}^{3} \mathrm{ha}^{-1}\right)$ was using data resulted from the 2010 periodically carried out comprehensive forest inventory (IHMB) of PT SSS. Biomass conversion to carbon (C) factor of 0.47 was used to estimate carbon stock, and estimation of the quantity of $\mathrm{CO}_{2} \mathrm{e}$ was using carbon $(\mathrm{C})$ conversion to $\mathrm{CO}_{2}$ e factor of 3.67 (IPCC in GOFC-GOLD 2009).

Carbon credit estimation Estimation of carbon credit number in every SFM scenarios (scenario 1-6) was

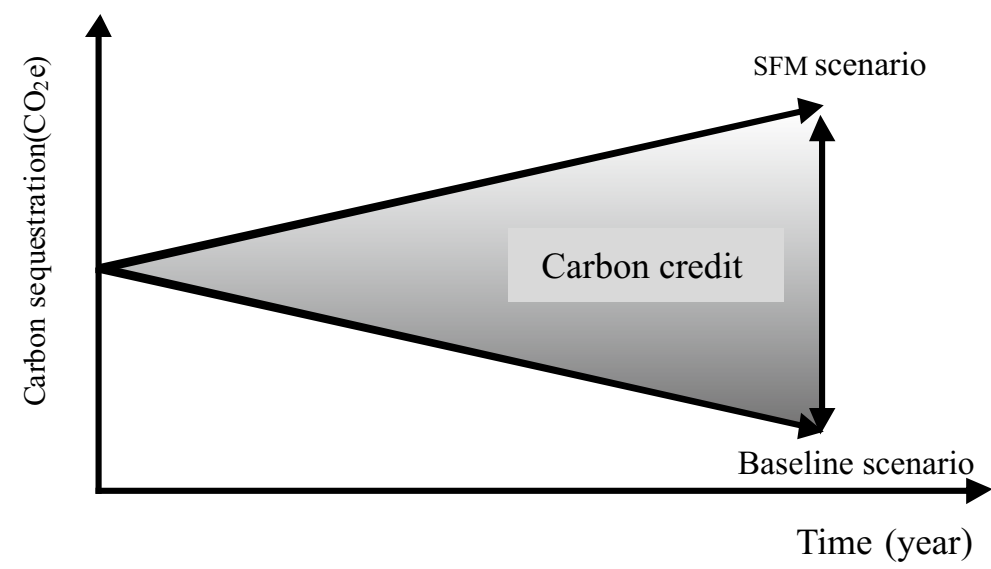

Figure 1 Credit carbon from sustainable forest management (SFM) practices area. 
compared to the baseline scenario. Credit carbon was accumulative of the annual differences of carbon stock between baseline scenario and SFM scenarios up to the end of the project (Figure 1).

Benefit analysis of carbon trading project Benefit analysis of carbon trading project was calculated from cost and benefit of each SFM scenario. A project was considered feasible when its net present value (NPV) was $>0$ and benefit cost ratio $(\mathrm{BCR})$ was $\geq 1$. Production cost of $\log \left(\right.$ IDR $\left.\mathrm{m}^{-3}\right)$ included in the cost of forest establishment such as planting and rehabilitation cost referring to financial report of PT SSS 2009, 2010 and 2011 that assumed to be equivalent, i.e. IDR850,000 $\mathrm{m}^{-3}$. Transaction cost was referring to the Permenhut No. P.36/Menhut-II/2009 that was based on voluntary carbon standard (VCS) scheme. In VCS scheme, economic value approach of 5 years period of the project was used in economic calculation of carbon, in which the payment of carbon project was done by ex-post full credit. The price of carbon used was USD4 $\mathrm{tCO} 2 \mathrm{e}^{-1}$ referring to carbon project (REDD) of Ulu Masen, Aceh, and 5 and 6 tCO2 $\mathrm{e}^{-1}$ referring to price variation when the price of carbon increase. Sensitivity analysis was used to distinguish the output value of the project when differences in the principle of cost and benefit calculation occurred. Those differences occurred at the interest level of 10,12 , and 14\%; when transactions cost is flat and $20 \%$ increase or $20 \%$ decrease; and when the log price is flat and increase or decrease about $15 \%$.

Recovery period of the stand carbon stock of LOA The recovery period of carbon stock was prepared based on the graph of carbon stock development at baseline scenario and that of SFM scenarios during the project. It brought about the regression lines describing the duration of recovery period of the stand carbon stock of LOA. Point at which the stand carbon stock potential of LOA returned to the initial level (before harvesting) is the duration of recovery period of carbon stock.

\section{Results and Discussion}

Carbon stock change After 30 years, carbon stock of stand in each SFM scenario decreased. The decreased was dependent on the annual allowable cutting (AAC) (Table 2). At the end of the project, the highest reduction $(19.22 \%)$ in carbon stock occurred at the baseline scenario and the carbon stock of SFM scenario- 6 increased by $0.77 \%$. The AAC of baseline scenario and that of SFM scenario-6 was IDR91,006.47 $\mathrm{m}^{3}$ year $^{-1}$ (the highest) and 56,807.14 $\mathrm{m}^{3}$ year $^{-1}$ (the lowest), respectively. It is clearly shown by Table 2 that harvesting intensity (AAC) strongly influenced the reduction of carbon stock after stand cutting. Evaluation on baseline scenario and SFM scenario-4 indicated that implementation of RIL increased carbon stock by $13.41 \%$ compared to that with CL implementation. After post harvesting of 30 years, RIL practiced in Sabah-Malaysia has brought about residual stands that maintained $27.78 \%$ higher in carbon stock compared to that of CL (Putz et al. 2008b). Increasing the limit of felling dbh increased carbon stock better than extending the harvesting duration. Increasing the felling $\mathrm{dbh}$ from $40-50 \mathrm{~cm}$ or from $50-60 \mathrm{~cm}$ increased carbon stock as much as $5.31 \%$, and extending the duration of harvesting from 30 years to 35 years increased carbon stock of $4.44 \%$. Figure 2 indicates the differences of carbon stock from the

Table 2 Carbon stock potential at the initial and end of the project $\left(\mathrm{tCO}_{2} \mathrm{e}\right.$ ha $\left.{ }^{-1}\right)$

\begin{tabular}{|c|c|c|c|c|c|c|c|}
\hline & \multicolumn{7}{|c|}{ Scenario } \\
\hline & Baseline & 1 & 2 & 3 & 4 & 5 & 6 \\
\hline $\begin{array}{l}\text { Carbon stock at the project } \\
\text { initial }\left(\mathrm{tCO}_{2} \mathrm{e} \mathrm{ha}^{-1}\right)\end{array}$ & 374.06 & 374.06 & 374.06 & 374.06 & 374.06 & 374.06 & 374.06 \\
\hline $\begin{array}{l}\text { Carbon stock at the end of } \\
\text { project }\left(\mathrm{tCO}_{2} \mathrm{e} \mathrm{ha}^{-1}\right)\end{array}$ & 302.16 & 341.87 & 362.92 & 357.04 & 342.69 & 358.97 & 377.01 \\
\hline Carbon stock reduction (\%) & 19.22 & 8.61 & 2.98 & 4.55 & 8.40 & 4.05 & -0.77 \\
\hline
\end{tabular}

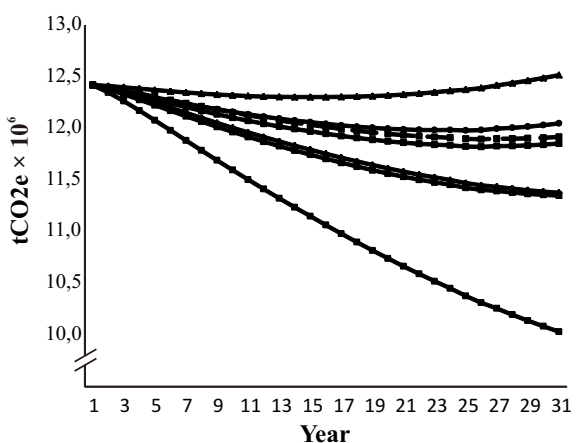

Figure 2 Carbon stock developments from the beginning to the end of the project (in the effective production area of 33.205 ha). Baseline $(-)$, scenario $1(-)$, scenario $2(-)$, scenario $3(-)$, scenario $4(-)$, scenario $5(\rightarrow)$, scenario $6(-)$. 
Table 3 Carbon credit at all of SFM scenarios

\begin{tabular}{lcccccc}
\hline & Scenario 1 & Scenario 2 & Scenario 3 & Scenario 4 & Scenario 5 & Scenario 6 \\
\hline $\begin{array}{l}\text { Accumulative } \\
\left(\mathrm{MtCO}_{2} \mathrm{e} \text { in 33.205 ha) }\right.\end{array}$ & 19.96 & 30.49 & 27.54 & 21.13 & 29.24 & 38.26 \\
\hline $\begin{array}{l}\text { Average per ha } \\
\left(\mathrm{tCO}_{2} \text { eha }^{-1} \text { yeari }\right.\end{array}$
\end{tabular}

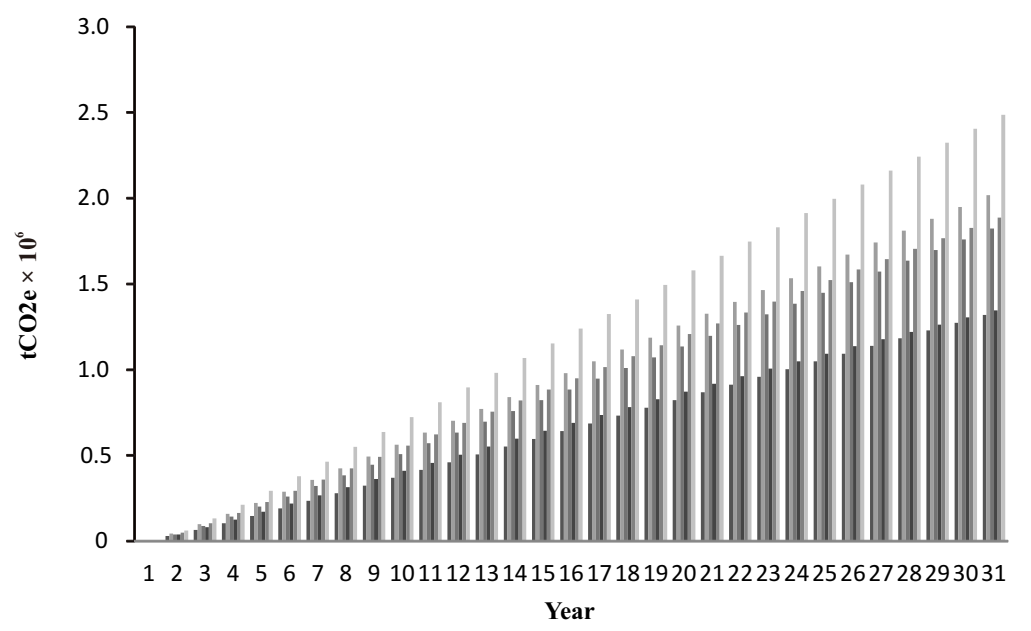

Figure 3 Annual credit carbon during the project $\left(\mathrm{tCO}_{2} \mathrm{e}\right.$ year $\left.{ }^{-1}\right)$. Scenario $1(\square)$, scenario $2(\square)$, scenario $3(\square)$, scenario $4(\square)$, scenario $5(\square)$, scenario $6(\square)$.

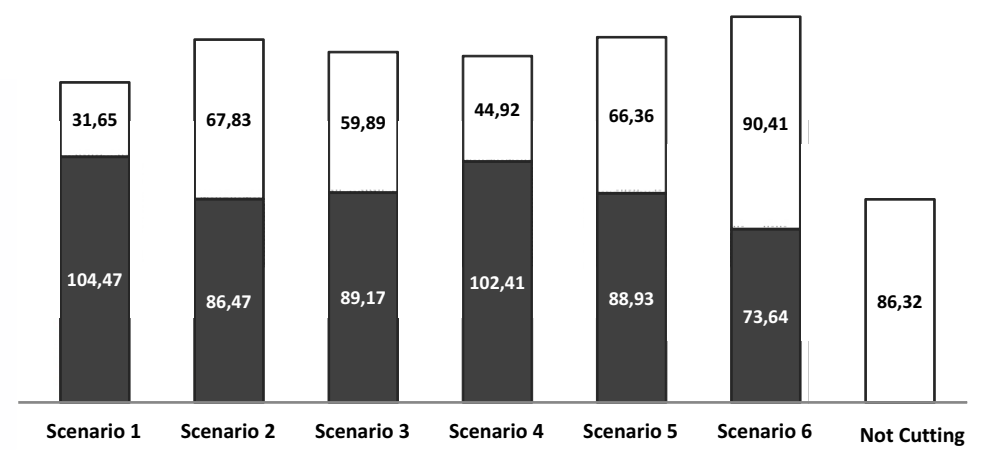

Figure 4 Total income of the carbon trading project at carbon price of USD4 $\mathrm{tCO}_{2} \mathrm{e}^{-1}$ and the interest rate of $12 \%$ (IDR billion). Wood ( $\square)$, carbon ( $\square)$.

beginning to the end of the project.

Carbon credit Although carbon stock decreased at all SFM scenarios, however the scenarios maintained a higher carbon stock than that of baseline scenario. The amount of carbon stock in each of the scenario was inversely related to the harvesting intensity. At 30 years accumulative carbon sequestration of each scenario is the collected carbon credit. Therefore, scenario with the lowest AAC has brought about the highest carbon credit, as shown in scenario-6. AAC of scenario- 6 was $56,807.14 \mathrm{~m}^{3}$ year $^{-1}$ and its carbon credit was $38.26 \mathrm{MtCO}_{2} \mathrm{e}$ with an average of $38.41 \mathrm{tCO}_{2} \mathrm{e} \mathrm{ha}^{-1}$ year
(Table 3). Figure 3 indicates the amount of annual carbon credit during the project.

Financial analysis When MU involved in carbon trading project, the quantity of collected carbon credit can be sold that brought about a reasonably high income. For the purpose of financial analysis of the carbon trading project, few assumptions and price standards were used i.e. wood production cost of IDR $850,000 \mathrm{~m}^{-3}$, local community fee of IDR90,000 $\mathrm{m}^{-3}$, validation cost of USD7,500, verification cost of USD 20,000, certification cost of USD0.04 VER ${ }^{-1}$ (verified emission reduction) sold (Permenhut No. 
P.36/Menhut-II/2009), and carbon price of USD4, 5, and UDS6 $\mathrm{tCO}_{2} \mathrm{e}^{-1}$, where USD1 was equivalent to IDR9,000, preparation cost of REDD+ was USD32.8 ha ${ }^{-1}$ and operating cost was USD22.35 ha-1 (Ginoga et al. 2010). It was also assumed that all carbon credit (for 5 years) was sold out.

Financial analysis indicated that at carbon price of 4, 5 and $6 \mathrm{USDtCO}_{2} \mathrm{e}^{-1}$ and the annual interest rate of 10, 12, and $14 \%$, all of the current SFM scenarios of carbon project were satisfying the criterion of $\mathrm{NPV} \geq 0$ and $\mathrm{BCR} \geq 1$, and therefore all were feasible to be developed. As an example, at the carbon price of USD4 $\mathrm{tCO}_{2} \mathrm{e}^{-1}$ and the interest rate of $12 \%$, incomes from carbon stock service were reasonably high, thus total income from wood and carbon sequestration service was exceeding the income from merely selling wood (baseline scenario) (Figure 4).

Figure 4 indicates that when scenario-6 was implemented, income from wood utilization was lower due to the decreased of AAC (IDR73.64 billion). However, the income of carbon sequestration were extremely high (IDR90.41 billion), therefore total income sharply increased to IDR164.04 billion or IDR5.47 bilion year ${ }^{-1}$, exceeding the other scenarios. In case that MU of PT SSS decides not to carry out wood harvesting and it is dependent only on carbon project income, total income during the carbon project was low, i.e. as much as IDR86.32 billion or approximately of IDR 2.88 bilion year ${ }^{-1}$ only.

Sensitivity analysis indicated that although both transaction cost and log price were respectively 20 and $15.4 \%$ changed, carbon project was remain feasible to be conducted. It also indicated that carbon project was very sensitive to the price change of log. As an example, sensitivity analysis at carbon price of USD4 $\mathrm{tCO}_{2} \mathrm{e}^{-1}$ and the interest rate of $12 \%$ indicated that when log price increased or decreased by $15.4 \%$ (to IDR1.5 million or IDR1.1 million), then at an equivalent transaction cost, the total of net income changed (increased or decreased) as much as $67.13 \%$. Nevertheless, when transaction cost was $20 \%$ increasing or decreasing at an equivalent $\log$ price, then the change of net income was only as much as $5.64 \%$. It can be said that the price of $\log$ and its accompanying costs (wood production cost, forest resources tax, reforestation fund, property and land tax, and third party fees) were important variables influencing the profit of MU. Permenhut No. P.36/Menhut-II/2009 ruled the distribution of financial benefit from carbon sequestration trading, i.e. $60 \%$ for MU and 20\% each for the government and local community around the forests. Therefore, MU, central and local government, and local community will benefit from carbon trading carried out by the MU of PT SSS.

Recovery period of the LOA stand carbon stock Based on the development of carbon stock (Figure 2), quadratic regression lines describing the development of carbon stock of the LOA stand from the beginning of the project to the stage of carbon stock before cutting can be formulated. The point in which carbon stock potential returned is the duration required to recover. Period of carbon stock recovery is the point in the regression line where carbon stock potential has returned to the beginning (before cutting). The duration of the LOA stand carbon stock recovery of every scenario is dependent on its annual allowable cut (AAC). Table 4 represents the equation lines of carbon stock development and Figure 5 depicts the carbon stock recovery period of LOA stand.

Figure 5 indicates that the increased of harvested wood volume (AAC) increased the period of recovery, as indicated by the baseline scenario. On the other hand, the shortest period of recovery (27 years) occurred at the scenario- 6 (lowest AAC). This shortest period of recovery was in a small part due to additional carbon sequestration from enrichment and rehabilitation planting. In case that additional carbon from enrichment and rehabilitation planting were neglected, the duration of recovery of the scenario- 6 was increased to 30 years. The duration of recovery period of the baseline scenario, scenario-1, scenario-2, scenario-3, scenario-4, scenario-5, and scenario6 were 137 years, 76 years, 46 years, 54 years, 84 year, 56 years and 27 years, respectively. Except for that of scenario6 , the duration of recovery period of all other scenarios was greater than its cutting rotation. This finding is similar to those found elsewhere. Self recovery of LOA stand in tropical forests of France Guyana harvested with the intensity of $53.4 \mathrm{~m}^{3} \mathrm{ha}^{-1}$ (Blanc et al. 2009) and in Uganda harvested with the intensity of $14 \mathrm{~m}^{3} \mathrm{ha}^{-1}$ (Bonnell et al. 2011) were approximately 100 years and 95 years, respectively. Furthermore, about 45-100 years is required by LOA stand biomass in tropical forests to reach the stage of primary forests (Shearman et al. 2012). Secondary succession to primary forests in opened area within tropical forests in Sumatera (West Sumatera, Jambi, South Sumatera, and Lampung) required an average of 117 years (Huc \& Rosalina 1981 in Anwar et al. 1984). Reduction of AAC shortened the

Table 4 Regression line equations of the development of LOA stand carbon stock

\begin{tabular}{ccc}
\hline Scenario & Line equation & $R^{2}$ \\
\hline Baseline & $Y=12,471,008.14-105.009,77 X+767,01 X^{2}$ & 0.99 \\
1 & $Y=12,451,784.53-61.930,94 X+822,94 X^{2}$ & 0.99 \\
2 & $Y=12,440,849.24-39.362,62 X+862,49 X^{2}$ & 0.99 \\
3 & $Y=12,443,345.64-45.701,02 X+853,46 X^{2}$ & 0.99 \\
4 & $Y=12,457,184.97-56.804,08 X+676,66 X^{2}$ & 0.99 \\
5 & $Y=12,447,320.67-39.439,73 X+712,34 X^{2}$ & 0.99 \\
6 & $Y=12,437,946.15-20.092,54 X+746,25 X^{2}$ & 0.99 \\
\hline
\end{tabular}




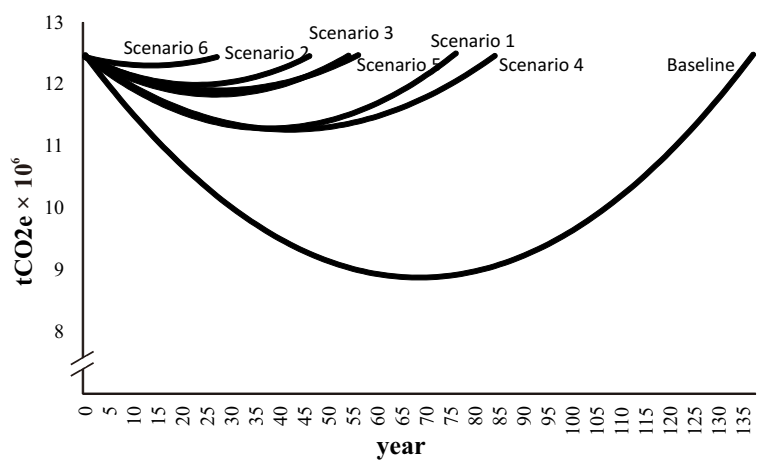

Figure 5 Recovery period of LOA stand carbon stock.

recovery period. The decreased of harvesting intensity increased the sustainability of timber product, carbon stock, and improved the structure and composition of forest vegetation species (Putz et al. 2012). These authors also proclaimed that the sustainability of timber forest product can be realized when harvesting rate is decreased through extension of cutting rotation into 50-100 years.

In the curve of recovery period existed a lowest point, after which the curve increased to the original mass of carbon. The duration from the basis point to the end point of the curve was called restoration period (Sasaki et al. 2011).

SFM, recovery period and carbon trading project The principal objective of SFM in production forests is the achievement of production role sustainability, in which sustainability of forest products is among its criterion. Indicator of that achievement is P2.5 indicator, i.e. residual stand condition (LEI 2000). Therefore, in the context of SFM, when forest ecosystem is required to continuously supplying goods and services, then the potential of residual stand must be incessantly sustained. In the other words, stand condition must be recovered to the initial stage before utilizing the stand in the following rotation.

The present research indicated that only the scenario- 6 resulted in recovery period ( 27 years) shorter than its cutting rotation. This was due to its lowest AAC compared to these of other scenarios. The implementation of scenario- 6 is thought to guarantee production sustainability, since after finishing the first rotation MU can proceed to the subsequent cutting rotation without any suspension. Therefore, related to the implementation of SFM, it is prudent that MU of PT SSS implement scenario-6 in the utilization of its wood. Implementation of scenario- 6 will bring about many benefits for the MU of PT SSS. These benefits include LOA stand will recover less than 30 years, higher total income when compared to other scenarios, involved in climate change mitigation, and low intensity cutting reduces defective impact of logging on residual stand as well as water and soil system. The average volume of felled tree in annual work plan 2011 of PT SSS was $9.16 \mathrm{~m}^{3}$. Therefore, at AAC of $56.807,14 \mathrm{~m}^{3}$ year $^{-1}$ of the scenario- 6 , only 6.5 trees $^{-1}$ was needed to be felled (Firma 2012). As much as 53\% of PT SSS area topography was classified as moderately steep to steep. Therefore, the number of felled tree per hectare is an important factor to be considered, i.e. the less the better.

To a certain level, the results of this study can be referred to prevent the decrease of production forest potential in the area of IUPHHK-HA. This can be done mainly when all MU of IUPHHK-HA implement SFM. Until June 2011, from 308 units of active IUPHHK-HA, only 5 units awarded with SFM certificate through voluntary certification scheme and 20 units awarded with good predicated SFM certificate through mandatory certification scheme (Rusolono \& Tiryana 2011). Furthermore, production sustainability can be realized when LOA stand potential has been recovered to the original state before subsequent cutting. In the long term this will prevent LOA stand degradation. It is important then for all MU of IUPHHK-HA, mainly those SFM certified, to recalculate its AAC. The best AAC should bring about a recovery period of LOA stand that is equivalent or shorter than its cutting rotation. Recalculation of AAC needs to be supported by regulation that bind and comply with all constituents. Succeed MU in reducing its AAC should be promoted to involve in carbon trading project. According to Permenhut No. P.36/Menhut-II/2009, MU can involve in the program of Carbon Stock or Sequestration Utilization Effort (UP PANRAP KARBON) as a form of carbon trading project in production forest through REDD+ mechanism. Involvement of MU in carbon trading project is expected to ensure its business continuity and MU obtains higher financial benefit. Prospective of financial benefit in carbon trading project is also expected to stimulate the involvement of MU of the other IUPHHK-HA to immediately implement SFM. Hence, the synergetic steps of the three aspects, i.e. SFM implementation, determination of $\mathrm{AAC}$ that ascertain the shortest recovery period, and involvement in carbon trading project is a solution leads to save production forest in Indonesia from the threat of degradation.

\section{Conclusion}

Carbon credit potential of LOA stand in PT SSS was sufficiently high and the quantity was influenced by the intensity of harvesting (AAC). Reduction of AAC based on recalculation and adjustment to the recovery period of residual stand brought about high carbon credit production and shorter recovery period of LOA stand. AAC reduction that will decrease the income of MU of the IUPHHK-HA from timber utilization product will be compensated by exceedingly higher income from carbon trading project through REDD+ scheme. Combination between AAC reduction program and carbon trading project is a strategic step to achieve the purpose of SFM in production forest and to contribute in climate change mitigation from forestry sector.

\section{References}

Anwar J, Damanik SJ, Hisyam N, Whitten Aj. 1984. Ekologi Ekosistem Sumatera. Yogyakarta: Gadjah Mada University Press.

Blanc Let al. 2009. Dynamics of aboveground carbon stocks in a selectively logged tropical forest. Ecological Applications 19(6):1397-1404. http://dx.doi.org/ 10.1890/08-1572.1. 
Bonnell TR, Reyna-Hurtado R, Chapman CA. 2011. Postlogging recovery time is longer than expected in an East African Tropical Forest. Forest Ecology and Management 261:855-864. http://dx.doi.org/10. 1016/j.foreco.2010.12.016.

Elias. 2001. Reduce Impact Logging. Buku 1. Bogor: Penerbit IPB Press.

Feldpausch TR, Jirka S, Passos CAM, Jasper F, Riha SJ. 2005. When big trees fall: damage and carbon export by reduce impact logging in southern Amazonia. Forest Ecology and Management 219 (2005): 119-215. http://dx.doi.org/10.1016/j.foreco.2005.09.003.

Firma F. 2012. Emisi karbon potensial akibat pemanenan kayu secara mekanis di hutan alam tropis. Kasus konsesi hutan PT Salaki Summa Sejahtera, Pulau Siberut, Provinsi Sumatera Barat [undergraduate thesis]. Bogor: Faculty of Forestry, Bogor Agricultural University.

Ginoga K, Nurfatrini F, dan Indartik 2010. Mekanisme insentif dan pendanaan REDD+. In: REDD+ and Forest Governance. Masripatin N, and Wulandari C. editors. Bogor: Pusat Penelitian dan Pengembangan Perubahan Iklim dan Kebijakan, Badan Penelitian dan Pengembangan Kehutanan, Kementerian Kehutanan.

[GOFC-GOLD] Global Observation of Forest and Land Cover Dynamics 2009. A Sourcebook of Methods and Procedures for Monitoring and Reporting Anthropogenic Greenhouse gas Emissions and Removals caused by Deforestation, Gains and Losses of Carbon Stock in Forest Remaining Forest, and Forestations. Alberta: Natural Resources Canada.

Indriyati IN. 2010. Kerusakan tegakan tinggal akibat pemanenan hutan di PT. Salaki Summa Sejahtera, Pulau Siberut, Sumatera Barat [undergraduate thesis]. Bogor: Faculty of Forestry, Bogor Agricultural University.

Istomo, Wibowo C, Hidayati N. 1999. Growth evaluation of Meranti (Shorea spp.) plantation at Haurbentes, BKPH Jasinga KPH Bogor, Perum Perhutani Unit III West Java. Journal of Tropical Forest Management 5(2):13-22.

Krisnawati H, Varis E, Kallio M, Kanninen M. 2011. Paraserianthes falcataria (L.) Nielsen. Ekologi, Silvikultur dan Produktivitas. Bogor: CIFOR.

[LEI] Lembaga Ekolabel Indonesia. 2000. Standar LEI Seri 5000: Kerangka Sistem Pengelolaan Hutan Produksi Lestari. Bogor: LEI.
[MoF] Ministry of Forestry. 2009. Peraturan Menteri Kehutanan No. P.30/Menhut-II/2009 tentang Tata Cara Pengurangan Emisi dari Deforestasi dan Degradasi Hutan (REDD). Jakarta: Departemen Kehutanan RI.

Partiani T. 2010. Limbah pemanenan kayu dan faktor eksploitasi di hutan alam PT Salaki Summa Sejahtera, Pulau Siberut, Sumatera Barat [undergraduate thesis]. Bogor: Faculty of Forestry, Bogor Agricultural University.

Pinard MA, Putz FE. 1996. Retaining forest biomass by reducing logging damage. BIOTROPICA 28(3):278295. http://dx.doi.org/10.2307/2389193.

Putz FE et al. 2008a. Improved tropical forest management for carbon retention. PLoS 6:1368-1369. http://dx.doi. org/10.1371/journal.pbio.0060166.

Putz FE, Sist P, Fredericksen T, Dykstra D. 2008b. Reduced impact logging: challenges and opportunities. Forest Ecology and Management 256(2008):1427-1433. http://dx.doi.org/10.1016/j.foreco.2008.03.036.

Putz FE et al. 2012. Sustaining conservation values in selectively logged tropical forest: the attained and the attainable. Conservation Letters (2012): 1-8.

Riyanto HD, Pamungkas BP. 2010. Model Pendugaan Produksi Tegakan Hutan Tanaman Sengon untuk Pengelolaan Hutan. Solo: Balai Penelitian Kehutanan.

Rusolono T, Tiryana T. 2011. Telaah terhadap ProyekProyek Berbasis Pengelolaan Hutan Lestari di Indonesia. Jakarta: Kementerian Kehutanan Republik Indonesia-International Tropical Timber Organizatian (ITTO).

Sasaki N, Cheng K. 2011. Managing production forest for timber production and carbon emission reduction under the REDD+ scheme. Conference of the parties to the UNCC in Durban, South Africa.

Sasaki N et al. 2011. Approaches to classifying and restoring degraded tropical forest for the anticipated REDD+ climate change mitigation mechanism. iForest-Journal Biogeosciences and Forestry 4:1-6. http://dx.doi.org/ 10.3832/ifor0556-004.

Shearman P. Bryan J, Laurance WF. 2012. Are we approaching 'peak timber' in the tropics? Biological Conservation 151:17-21. http://dx.doi.org/10.1016 /j.biocon.2011.10.036. 